\title{
Kadar Procalcitonin pada Anak dengan Demam Neutropenia
}

\section{Finia Cahayasari, Lelani Reniarti, Alex Chairulfatah}

Departemen Ilmu Kesehatan Anak Fakultas Kedokteran Universitas Padjadjaran/Rumah Sakit Dr. Hasan Sadikin, Bandung

Latar belakang. Demam neutropenia merupakan penyulit yang sering terjadi pada anak dengan penyakit keganasan sehingga menyebabkan morbiditas dan mortalitas yang tinggi. Sebagian besar demam neutropenia disebabkan oleh bakteri, sehingga perlu diberikan terapi empiris dengan antibiotik spektrum luas. Pemberian antibiotik bukan tidak berbahaya, karena itu diperlukan penanda bahwa demam yang terjadi disebabkan oleh bakteri. Procalcitonin (PCT) merupakan penanda terjadinya respons inflamasi tubuh yang disebabkan oleh bakteri.

Tujuan. Untuk mengetahui nilai diagnostik PCT sebagai penanda infeksi bakteri pada anak keganasan dengan demam neutropenia.

Metode. Penelitian potong lintang dilakukan sejak bulan Januari sampai Agustus 2011 di Rumah Sakit Dr. Hasan Sadikin Bandung, pada 49 pasien usia 1-13 tahun dengan demam neutropenia pada berbagai kasus keganasan. Sediaan darah untuk pemeriksaan biakan dan kadar PCT dilakukan pada saat pasien masuk rumah sakit atau pertama kali demam dan hari ke-5 untuk pemeriksaan PCT kedua. Penelitian kami telah disetujui oleh Komite Etik RS Dr. Hasan Sadikin Bandung. Analisis statistik menggunakan chi-square, Mann Whitney, uji t, dan korelasi rank Spearman.

Hasil. Dari 49 subjek penelitian ditemukan 18 (37\%) dengan hasil biakan bakteri positif dan 31 (69\%) tidak ditemukan bakteri. Pada pasien dengan hasil biakan bakteri positif ditemukan perbedaan bermakna dibanding dengan hasil biakan negatif dalam jumlah leukosit $(\mathrm{p}=0,020)$, absolute neutrophyl count (ANC) $(\mathrm{p}=0,020)$, dan kadar PCT $(\mathrm{p}=0,021)$ pada pemeriksaan awal. Demikian pula pemeriksaan pada hari ke-5 terdapat perbedaan bermakna dalam jumlah leukosit $(p=0,003)$, ANC $(p=0,002)$, dan kadar PCT ( $\mathrm{p}<0,001)$. Pada kelompok biakan darah positif jumlah leukosit, ANC, dan kadar PCT pada pemeriksaan awal dibandingkan dengan pemeriksaan hari ke- 5 tidak menunjukkan perbedaan yang bermakna. Terdapat korelasi negatif antara PCT dan ANC $\left(r_{s}-0,598 ; p=0,001\right)$. Kadar PCT >0,84 ng/mL memiliki sensitivitas $77,8 \%$; spesifisitas $87,1 \%$; dan akurasi $83,7 \%$ dalam mendeteksi kemungkinan infeksi bakteri pada pasien demam neutropenia.

Kesimpulan. Procalcitonin mempunyai nilai diagnostik yang baik untuk memprediksi bakteremia pada demam neutropenia. Sari Pediatri 2012;14(2):104-9.

Kata kunci: absolute neutrophyl count, demam neutropenia, procalcitonin

\footnotetext{
Alamat korespondensi:

Prof. dr. Alex Chairulfatah, Sp.A(K), Departemen Ilmu Kesehatan Anak Fakultas Kedokteran Universitas Padjadjaran/ RS dr. Hasan Sadikin, Jl. Pasteur 38 Bandung 40163, Telp. (022) 2035957, Fax. (022) 2034426.

E-mail:dianpus@bdg.centrin.net.id
} 


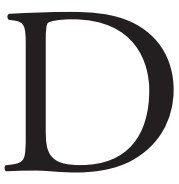
emam neutropenia merupakan komplikasi yang umum terjadi pada anak pasien keganasan dan merupakan salah satu penyebab morbiditas dan mortalitas yang tinggi. ${ }^{1-5}$ Data European Organization for Research and Treatment of Cancer (EORTC) tahun 1985-2000 mortalitas demam neutropenia $8,5 \%{ }^{6}$ Studi di Singapura didapatkan mortalitas $8,8 \%,{ }^{7}$ sedangkan $48 \%$ angka kejadian demam neutropenia terjadi di Rumah Sakit Dr. Hasan Sadikin, Bandung. ${ }^{4}$

Sekitar 60\% demam neutropenia disebabkan oleh bakteri dengan ataupun tanpa bakteremia. Progresivitas infeksi pada pasien neutropenia dapat berlangsung sangat cepat dan keadaan infeksi bakteri pada awal penyakit sulit dibedakan dengan keadaan noninfeksi. Pemberian antibiotik bukan tidak menimbulkan masalah, yang antara lain berupa alergi, toksisitas, superinfeksi, dan resistensi. ${ }^{8}$ Panduan pemberian antibiotik berdasarkan hasil pemeriksaan biakan darah memerlukan waktu dan seringkali hasilnya negatif. Procalcitonin (PCT) merupakan penanda baru sistem inflamasi reaksi tubuh terhadap infeksi bakteri. Penelitian Gattas dan Cook ${ }^{9}$ menyatakan sensitivitas PCT untuk diagnosis bakteremia adalah 95\%. Penelitian Giamarellou dkk ${ }^{10}$ melaporkan median level PCT serum pada hari pertama demam 2,62 ng/mL pada pasien dengan klinis sepsis berat dibandingkan dengan $0,57 \mathrm{ng} / \mathrm{mL}$ dengan infeksi lokal. Penelitian Erten $\mathrm{dkk}^{11}$ membandingkan sensitivitas, spesifisitas, nilai prediksi positif dan negatif, nilai diagnostik, serta rasio kecenderungan positif PCT serum dalam penilaian derajat berat ringannya demam neutropenia. Penelitian untuk mengetahui kadar PCT pada anak dengan demam neutropenia di Rumah Sakit Dr. Hasan Sadikin Bandung belum pernah dilakukan.

Pada penelitian kami diteliti kadar PCT pada pasien demam neutropenia untuk mengetahui kadar PCT dan diharapkan dapat memperkuat alasan pemberian antibiotik.

\section{Metode}

Penelitian dilakukan di Departemen/SMF Ilmu Kesehatan Anak Rumah Sakit Dr. Hasan Sadikin Bandung pada bulan Januari-Agustus 2011. Orangtua atau wali memberikan persetujuan tertulis (informed consent) setelah diberi informasi secara lengkap dan dimengerti untuk mengikutsertakan anaknya dalam penelitian ini. Kriteria inklusi adalah anak usia 1-14 tahun yang memenuhi kriteria demam neutropenia, sedangkan kriteria eksklusi adalah pasien gizi buruk, pasien yang telah mendapat terapi antibiotik sebelumnya, dan pasien demam karena reaksi transfusi.

Penelitian observasional analitik rancangan potong lintang (cross sectional). Pemilihan sampel dilakukan secara consecutive sampling, yaitu semua anak berusia 1-14 tahun yang memenuhi kriteria inklusi dirawat di Ruang Rawat Anak Rumah Sakit Dr. Hasan Sadikin Bandung. Identitas subjek dicatat meliputi nama, nomor rekam medis, usia, dan jenis kelamin, kemudian dilakukan aloanamnesis meliputi gejala yang timbul, dilakukan pemeriksaan fisis, dan pemeriksaan laboratorium. Pada saat dirawat atau hari pertama demam dilakukan pemeriksaan biakan darah, jumlah leukosit, absolute neutrophyl count (ANC), dan PCT. Pada hari ke-5 dilakukan pemeriksaan jumlah leukosit, ANC, dan PCT.

Secara statistik dilakukan analisis bivariabel untuk menentukan variabel lain yang berhubungan dengan biakan darah, yaitu jenis kelamin, jumlah leukosit, ANC, dan kadar PCT. Selanjutnya dilakukan analisis korelasi ANC dan PCT dengan biakan darah. Untuk menentukan nilai diagnostik dilakukan dengan metode receiver operating characteristic (ROC). Kemaknaan ditentukan berdasarkan nilai $\mathrm{p}<0,05$. Analisis data menggunakan program SPSS for windows versi 17.0. Penelitian mulai dilaksanakan setelah mendapatkan persetujuan Komite Etik Penelitian Kesehatan Fakultas Kedokteran Universitas Padjadjaran/ RS Dr. Hasan Sadikin Bandung.

\section{Hasil}

Di antara 49 subjek penelitian didapatkan (88\%) pasien leukemia. Subjek penelitian terdiri dari 30 (61\%) laki-laki dan 19 (39\%) perempuan (Tabel 1). Delapanbelas subjek (37\%) menunjukkan hasil biakan darah positif, kuman terbanyak yang berhasil diisolasi adalah Staphylococcus aureus (39\%). Pada kelompok dengan hasil biakan bakteri yang positif jum lah leukosit, ANC, dan PCT pada hari ke-1 dan hari ke-5 berbeda bermakna dibandingkan dengan kelompok biakan negatif. Perbedaan yang sangat bermakna ditemukan pada variabel kadar PCT $(\mathrm{p}<0,001)$ (Tabel 2).

Pada kelompok dengan biakan bakteri yang positif, tidak ada perbedaan yang bermakna antara 
Tabel 1. Karakteristik subjek penelitian berdasarkan hasil biakan darah

\begin{tabular}{lccc}
\hline & \multicolumn{2}{c}{ Biakan darah } & \multirow{2}{*}{$\mathrm{p}$} \\
\cline { 2 - 3 } Karakteristik & $\begin{array}{c}\text { Positif } \\
\mathrm{n}=18\end{array}$ & $\begin{array}{c}\text { Negatif } \\
\mathrm{n}=31\end{array}$ & \multirow{2}{*}{$0,996^{\mathrm{a}}$} \\
\hline $\begin{array}{l}\text { Jenis kelamin (\%) } \\
\text { Laki-laki } \\
\text { Perempuan }\end{array}$ & $11(22)$ & $19(39)$ & \\
Usia (tahun) & $7(14)$ & $12(25)$ & \\
$\quad$ Rerata (SB) & & & $0,547^{\mathrm{b}}$ \\
$\quad$ Rentang & $6,4(3,1)$ & $5,9(2,9)$ & \\
\hline
\end{tabular}

${ }^{\mathrm{a}}=\mathrm{Uji}$ chi-square; ${ }^{\mathrm{b}}=\mathrm{Uji} \mathrm{T}$ tidak berpasangan

Tabel 2. Hasil pemeriksaan laboratorium

\begin{tabular}{|c|c|c|c|}
\hline \multirow[b]{2}{*}{ Karakteristik } & \multicolumn{2}{|c|}{ Biakan darah } & \multirow[b]{2}{*}{ Kemaknaan } \\
\hline & $\begin{array}{l}\text { Positif } \\
\mathrm{n}=18\end{array}$ & $\begin{array}{c}\text { Negatif } \\
n=31\end{array}$ & \\
\hline \multicolumn{4}{|l|}{ Leukosit awal } \\
\hline Rerata (SB) & $1566,7(1230,5)$ & $3892,3(6259,6)$ & $2,334^{a}$ \\
\hline Median & 1350 & 2200 & $\mathrm{p}=0,020$ \\
\hline Rentang & $100-4700$ & $600-30200$ & \\
\hline \multicolumn{4}{|c|}{ Leukosit hari ke-5 } \\
\hline Rerata (SB) & $1947,1(1823,5)$ & $4367,1(4496,1)$ & $3,120^{\mathrm{a}}$ \\
\hline Median & 1500 & 3300 & $\mathrm{p}=0,003$ \\
\hline Rentang & $300-7100$ & $600-19800$ & \\
\hline \multicolumn{4}{|l|}{ ANC awal } \\
\hline Rerata (SB) & $317,7(308,4)$ & $517,5(263,7)$ & $2,332^{a}$ \\
\hline Median & 233,5 & 532 & $\mathrm{p}=0,020$ \\
\hline Rentang & $10-1008$ & 0-992 & \\
\hline \multicolumn{4}{|l|}{ ANC hari ke-5 } \\
\hline Rerata (SB) & $393,9(437,3)$ & $895,1(614,3)$ & $3,084^{\mathrm{a}}$ \\
\hline Median & 231 & 704 & $\mathrm{p}=0,002$ \\
\hline Rentang & $44-1392$ & $35-2112$ & \\
\hline \multicolumn{4}{|l|}{ PCT awal } \\
\hline Rerata (SB) & $11,1(19,3)$ & $0,5(0,6)$ & $4,821^{\mathrm{b}}$ \\
\hline Median & 1,1 & 0,3 & $\mathrm{p}=0,021$ \\
\hline Rentang & $0,1-64,3$ & $0,1-2,7$ & \\
\hline \multicolumn{4}{|l|}{ PCT hari ke-5 } \\
\hline Rerata (SB) & $11,6(18,5)$ & $0,7(1,1)$ & $4,276^{\mathrm{b}}$ \\
\hline Median & 1,2 & 0,2 & $\mathrm{P}<0,001$ \\
\hline Rentang & $0,1-54,6$ & $0,02-4,6$ & \\
\hline
\end{tabular}

Keterangan: $\mathrm{a}=$ Mann-Whitney $\mathrm{U}$; $\mathrm{b}=\mathrm{Uji} \mathrm{t}$

hasil pemeriksaan hari pertama jumlah leukosit, ANC, dan PCT dibandingkan dengan hasil pemeriksaan hari ke-5 (Tabel 3).

Hasil penelitian menunjukkan bahwa terdapat korelasi negatif antara kadar PCT dan nilai ANC. Makin tinggi kadar PCT, makin rendah nilai ANC $\left(\mathrm{r}_{\mathrm{s}}:-0,598 ; \mathrm{p} 0,001\right)$ (Tabel 4).

Untuk mencari titik potong dari jumlah leukosit, ANC, dan kadar PCT dalam mendeteksi bakteremia dilakukan analisis ROC. Sensitivitas, spesifisitas, dan nilai akurasi kadar PCT $>0,84$ lebih baik dibandingkan dengan jumlah leukosit dan ANC (Tabel 5). 
Tabel 3 Hasil pemeriksaan laboratorium awal dan kedua pada biakan darah positif

\begin{tabular}{|c|c|c|c|}
\hline \multirow{2}{*}{ Variabel } & \multicolumn{2}{|c|}{ Biakan darah positif } & \multirow{2}{*}{ Kemaknaan } \\
\hline & Awal & Hari ke- 5 & \\
\hline \multicolumn{4}{|l|}{ Leukosit } \\
\hline Rerata (SB) & $1566,7(1230,5)$ & $1947,06(1823,50)$ & $1,493^{\mathrm{a}}$ \\
\hline Median & 1350 & 1500,00 & $\mathrm{p}=0,136$ \\
\hline Rentang & $100-4700$ & $300-7100$ & \\
\hline \multicolumn{4}{|l|}{ ANC } \\
\hline Rerata (SB) & $317,7(308,4)$ & $393,94(437,33)$ & $0,781^{a}$ \\
\hline Median & 233,5 & 231 & $\mathrm{p}=0,435$ \\
\hline Rentang & $10-1008$ & $44-1392$ & \\
\hline \multicolumn{4}{|l|}{ PCT } \\
\hline Rerata (SB) & $11,1(19,3)$ & $11,6(18,5)$ & $0,151^{\mathrm{b}}$ \\
\hline Median & 1,1 & 1,2 & $\mathrm{p}=0,882$ \\
\hline Rentang & $0,1-64,3$ & $0,1-54, .6$ & \\
\hline
\end{tabular}

Keterangan: $a=U j i$ Wilcoxon; $b=$ Uji t data berpasangan

Tabel 4. Korelasi antar variabel

\begin{tabular}{lcccc}
\hline \multirow{2}{*}{ Korelasi } & \multicolumn{2}{c}{ Biakan darah positif } & \multicolumn{2}{c}{ Biakan darah negatif } \\
\cline { 2 - 5 } & $\mathrm{r}_{\mathrm{s}}$ & $\mathrm{p}$ & $\mathrm{r}_{\mathrm{s}}$ & $\mathrm{p}$ \\
\hline ANC1 dengan $\operatorname{logPCT} 1$ & $-0,195$ & 0,438 & $-0,172$ & 0,362 \\
ANC2 dengan logPCT2 & $-0,298$ & 0,245 & $-0,598$ & 0,001 \\
\hline
\end{tabular}

Keterangan: $r_{s}=$ koefisien korelasi Rank Spearman

Tabel 5. Cut-off point leukosit, ANC, dan procalcitonin

\begin{tabular}{lccc}
\hline Variabel & Leukosit<1400 & ANC $\leq 84$ & PCT $>0,84$ \\
\hline Sensitivitas (\%) & 55,6 & 44,4 & 77,8 \\
Spesifisitas (\%) & 77,4 & 96,8 & 87,1 \\
Akurasi (\%) & 69,4 & 77,5 & 83,7 \\
\hline
\end{tabular}

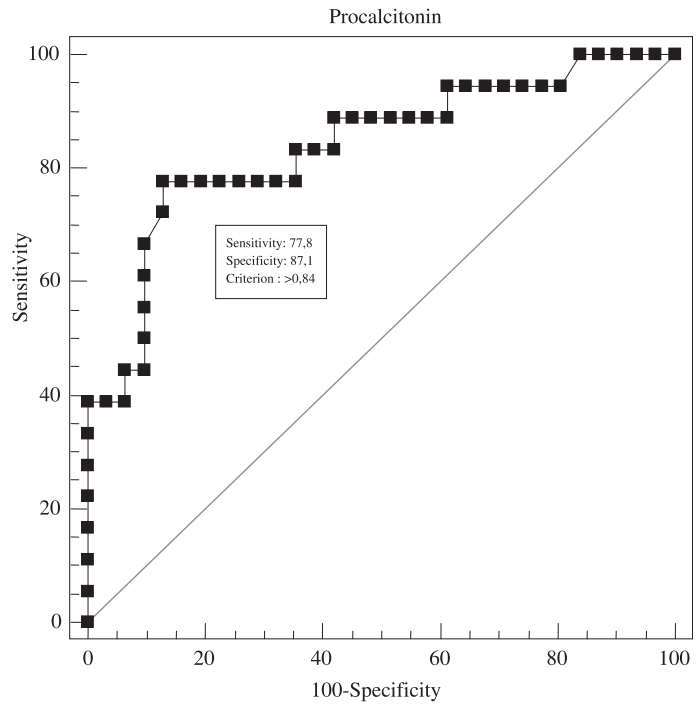

Gambar 1. Kurva ROC (receiver operating characteristic) procalcitonin

\section{Pembahasan}

Sekitar 60\% demam neutropenia disebabkan oleh bakteri dengan ataupun tanpa bakteremia. Progresivitas infeksi bakteri pada pasien neutropenia dapat berlangsung sangat cepat, sehingga antibiotik spektrum luas harus segera diberikan. ${ }^{5}$ Pemberian antibiotik bukan berarti tanpa risiko, antara lain berupa alergi, toksisitas, superinfeksi, dan juga kemungkinan resistensi yang ditimbulkan. ${ }^{8}$ Biakan darah sebagai baku emas infeksi bakteri yang terjadi memerlukan waktu dan seringkali hasilnya negatif, sehingga untuk lebih memperkuat alasan pemberian antibiotik diperlukan penanda bahwa demam neutropenia yang terjadi disebabkan oleh bakteri. ${ }^{12-14}$

Telah dilakukan berbagai penelitian dalam mengevaluasi nilai diagnostik berbagai penanda inflamasi seperti interleukin (IL)-6, IL-8, C-reactive 
protein (CRP), dan PCT dalam mengidentifikasi pasien yang berisiko tinggi untuk mengalami sepsis. Peningkatan kadar PCT serum ditemukan pada infeksi bakteri berat dengan tanda dan gejala sistemik, sehingga PCT diajukan sebagai penanda inflamasi untuk diagnosis infeksi bakteri pada beberapa tahun terakhir. ${ }^{12,13,15}$

Penelitian yang dilakukan pada subjek yang menderita demam tanpa sumber yang jelas (fever without source/FWS) menunjukkan bahwa PCT mempunyai sensitivitas dan spesifisitas yang lebih baik dibanding pemeriksaan CRP, jumlah leukosit, dan ANC dalam memprediksi infeksi bakteri yang berat. ${ }^{9,16}$ Crain $\mathrm{dkk}^{17}$ merekomendasikan panduan pemberian antibiotik pada pasien dengan gejala sepsis berdasarkan kadar PCT sebagai berikut, yaitu $<0,1$ $\mathrm{ng} / \mathrm{mL}$ antibiotik sangat tidak dianjurkan, $<0,25$ $\mathrm{ng} / \mathrm{mL}$ antibiotik tidak dianjurkan, $>0,25 \mathrm{ng} / \mathrm{mL}$ antibiotik dianjurkan, dan $>0,5 \mathrm{ng} / \mathrm{mL}$ antibiotik sangat dianjurkan.

Nilai ANC pada subjek dengan biakan darah positif lebih rendah dari subjek dengan biakan darah negatif, baik pada pemeriksaan awal maupun pada pemeriksaan hari ke-5. Nilai ANC menggambarkan derajat berat ringannya demam neutropenia yang terjadi. Hal tersebut menunjukkan bahwa subjek dengan ANC yang rendah lebih rentan terkena infeksi bakteri. Sesuai dengan penelitian yang dikemukakan oleh Meir $\mathrm{dkk}^{5}$ bahwa angka kejadian infeksi dan derajat berat ringannya infeksi berhubungan dengan nilai ANC. Pada nilai ANC yang rendah kejadian infeksi lebih sering dan lebih berat.

Kadar PCT rerata serum pada saat masuk pada subjek dengan biakan darah positif jauh lebih tinggi dibandingkan dengan subjek dengan biakan darah negatif $(11,1 \mathrm{ng} / \mathrm{mL}$ vs $0,5 \mathrm{ng} / \mathrm{mL}, \mathrm{p}<0,05)$, sehingga kadar PCT pada pemeriksaan awal dapat digunakan sebagai penanda infeksi bakteri, dengan demikian dapat memperkuat alasan pemberian antibiotik. Sesuai dengan penelitian yang dilakukan oleh Gattas dan Cook ${ }^{9}$ yang mengemukakan bahwa sensitivitas PCT untuk diagnosis bakteremia sebesar 95\%.

Kami melakukan pemeriksaan kadar PCT pada hari pertama dan hari ke-5, Gattas dan Cook ${ }^{9}$ menyatakan bahwa kadar pemantauan kadar PCT serum merupakan indikator yang sensitif untuk menilai keberhasilan pengobatan.

Pemeriksaan PCT hari ke-5 masih didapatkan kadar yang cukup tinggi pada subjek dengan biakan darah positif, walaupun tidak berbeda bermakna dibandingkan dengan pemeriksaan awal. Secara teoritis PCT baru ditemukan dalam plasma setelah 2 jam terinfeksi, konsentrasi mulai menetap setelah 4 jam, kemudian meningkat tajam pada 6 jam, dan tetap tinggi selama 8 sampai 24 jam dengan waktu paruh PCT 25-30 jam. ${ }^{17-19}$

Terdapat beberapa kemungkinan mengapa kadar PCT masih tinggi pada kelompok dengan biakan yang positif, yaitu pertama perburukan klinis yang terjadi. Muller dan Becker ${ }^{20}$ mengemukakan bahwa perburukan klinis pasien demam neutropenia berbanding lurus dengan peningkatan kadar PCT. Peningkatan kadar PCT ini lebih bermakna dibandingkan dengan parameter lain yaitu jumlah leukosit, CRP, dan suhu tubuh. Pemeriksaan serial PCT dengan kecenderungan meningkat menunjukkan respons inflamasi terhadap infeksi yang semakin berat, sebaliknya apabila menurun menunjukkan perbaikan keadaan pasien. ${ }^{9,20}$

Kemungkinan yang kedua adalah resistensi terhadap antibiotik yang digunakan. Temuan kami dari isolat bakteri yang berhasil diisolasi 33\% resisten terhadap gentamisin dan $20 \%$ resisten terhadap ceftazidim, kedua antibiotik tersebut masih sering dipakai dalam terapi demam neutropenia.

Kami menemukan korelasi negatif antara nilai ANC dan kadar PCT serum $\left(r_{s}-0,598 ; p<0,001\right)$. Hal tersebut menunjukkan bahwa semakin tinggi nilai ANC, maka kadar PCT semakin rendah, dan sebaliknya. Sesuai dengan penelitian Erten $\mathrm{dkk}^{11}$ yang menemukan kadar PCT yang jauh lebih tinggi pada subjek dengan demam neutropenia berat.

Nilai cut-off point kadar PCT $>0,84 \mathrm{ng} / \mathrm{mL}$ memiliki sensitivitas $77,8 \%$; spesifisitas $87,1 \%$; dan akurasi $83,7 \%$ dalam mendeteksi kemungkinan bakteremia pada pasien demam neutropenia. Hasil tersebut jauh lebih baik dibandingkan dengan jumlah leukosit dan ANC.

\section{Kesimpulan}

Procalcitonin dapat dijadikan penanda bakteremia pada anak demam neutropenia, sehingga dapat memperkuat alasan pemberian antibiotik selama hasil biakan darah belum tersedia. Nilai cut-off point PCT 0,84 ng/mL, memiliki sensitivitas $77,8 \%$; spesifisitas $87,1 \%$; dan akurasi $83,7 \%$ dalam memprediksi bakteremia pada pasien demam neutropenia. 


\section{Daftar pustaka}

1. Sharma A, Lokeshwar. N. Febrile neutropenia in haematological malignancies. Rev Article 2005;51:42-8.

2. Gunes D, Mutafoglu K, Cetinkaya H, Arslan H, Cakir D, Olgun N. Febrile neutropenic episodes in children with lymphoma and malignant solid tumors. J Pediatr Inf 2010;4:1-8.

3. Meckler G, Lindemulder S. Fever and neutropenia in pediatrics patiens with cancer. Emerg Med Clin N Am 2009;27:525-44.

4. Gunawan S, Rampengan NH, Mantik MFJ, Rampengan TH. Febrile neutropenia in childhood leukemia: Manado experience 1997-2006. Paediatr Indones 2009;49:372-8.

5. Meir HM, Balawi IA, Meer HM, Nayel H, Al-Mobarak MF. Fever and granulocytopenia in children with acute lymphoblastic leukemia under induction therapy. Saudi Med J 2001;22:423-7.

6. Mendez AVA, Sapolnik R, Mendonça N. New guidelines for the clinical management of febrile neutropenia and sepsis in pediatric oncology patients. J Pediatr 2007;83:54-63.

7. Wetering VD, Witte MA, Kremer LCM, Offringa M, Scholten RJ, Caron HN. Efficacy of oral prophylactic antibiotics in neutropenic afebrile oncology patients: a systematic review of randomised controlled trials. Eur J Cancer 2005;41:1372-82.

8. Gallagher JC, MacDougall C. Antibiotics simplified. Edisi ke-2. Canada: Jones \& Bartlett; 2012.

9. Gattas DJ, Cook DJ. Procalcitonin as a diagnostic test for sepsis: health technology ssessment in the ICU. J Crit Care 2003;18:52-8.

10. Giamarellou H, Bourboulis EJG, Repoussis P, Galani L, Anagnostopoulos N, Grecka P, dkk. Potential use of procalcitonin as a diagnostic criterion in febrile neutropenia: experience from a multicenter study. Clin Microbiol Infect 2004;10:628-33.

11. Erten N, Genc S, Besisik SK, Saka B, Karan MA,
Tascioglu C. The predictive and diagnostic values of procalcitonin and C-reactive protein for clinical outcome in febrile neutropenic patients. J Chin Med Assoc 2004;67:217-21.

12. Faizal MAM, Goonasekera CD, Thevanesam V. Management of febrile neutropenia in childern. Sri Lanka J Child Health 2006;35:90-6.

13. Bhatia BD, Basu S. Newer diagnostic tests for bacterial diseases. Indian J Pediatr 2007;74:673-7.

14. Albarran M, Jode PM, Castorena G, Zubieta S, Arreola DT, Sanroman T, dkk. Procalcitonin and C-reactive protein serum levels as a markers of infection in a pediaric population with febrile neutropenia and cancer. J Pediatr Hematol Oncol 2009;26:414-25.

15. Lacour AG, Zamora SA, Gervaix A. Bedside procalcitonin and C-reactive protein tests in children with fever without localizing signs of infection seen in a referral center. Pediatrics 2003;112:1054-60.

16. Clec'h C, Ferriere F, Karoubi P, Fosse JP, Cupa M, Hoang P, dkk. Diagnostic and prognostic value of procalcitonin in patients with septic shock. Crit Care Med 2004;32:1166-9.

17. Crain MC, Müller B, Schuetz P. Procalcitonin and other biomarkers for the assessment of disease severity and guidance of treatment in bacterial infections. Adv Sepsis 2008;6:82-9.

18. Lopez AF, Cubels CL, Garcia JJG, Pou JF. Procalcitonin in pediatric emergency departments for the early diagnosis of invasive bacterial infections in febrile infants: results of a multicenter study and utility of a rapid qualitative test for this marker. Pediatr Infect Dis J 2003;22:895-903.

19. Muller B, White JC, Nylen ES, Snider RH, Becker KL, Habener JF. Ubiquitous expression of the calcitonin-I gene in multiple tissues in response to sepsis. J Clin Endocrinol Metab 2001;86:396-404.

20. Muller B, Becker KL. Procalcitonin: how a hormone became a marker and mediator of sepsis. Swiss Med Wkly 2001;131:595-602. 